\title{
Eksklamacje (wykrzyknienia) o funkcji emotywnej w dawnych i współczesnych tekstach nabożeństwa drogi krzyżowej
}

\section{Emotive Exclamations in Older and Contemporary Texts of the Stations of the Cross}

\author{
Agnieszka Sieradzka-Mruk \\ Wydział Polonistyki, Uniwersytet Jagielloński, \\ ul. Gołębia 20, 30-007 Kraków, Polska; \\ e-mail: agnieszka.sieradzka-mruk@uj.edu.pl
}

\begin{abstract}
Abstrakt
Artykuł przedstawia porównanie dawnych i współczesnych tekstów pod względem funkcji i częstości występowania eksklamacji. Analiza opiera się 100 tekstach nabożeństwa drogi krzyżowej wydanych przed soborem watykańskim II i 100 współczesnych tekstach. Okazuje się, że liczba wykrzyknień znacząco spada w ciągu ostatniego stulecia. W dawnym nabożeństwie eksklamacje są liczne i urozmaicone pod względem struktury. Obecnie pojawiają się pojedynczo i w specjalnych kontekstach, zwłaszcza w stylizacji i w użyciach ironicznych. Widoczny jest wpływ innych dyskursów i gatunków oraz sytuacji komunikacyjnej. Artykuł porusza także problem wyznaczników eksklamacji w tekstach pisanych i mówionych.
\end{abstract}

Słowa kluczowe: eksklamacja; funkcja emotywna; droga krzyżowa; dyskurs religijny.

\begin{abstract}
The article presents a comparison of older and more contemporary texts in respect of the functions and frequency of exclamations. The analysis is based on about 100 Polish texts used in Catholic ceremonies of the Stations of the Cross, published before the Second Vatican Council and 100 contemporary texts of the same devotional practice. It appears that the number of exclamations in contemporary texts has decreased radically. In the older material exclamations are numerous and have a variety of structures. In contemporary texts we find far fewer, usually in special contexts, especially in highly stylised and ironic ones. One can see the influence of other discourses and genres and the communicative situation as well. The paper also deals with indicators of exclamations in spoken and written texts.
\end{abstract}

Keywords: exclamation; emotive function; Stations of the Cross; religious discourse.

Niniejsze opracowanie stanowi cząstkowy rezultat badań nad przemianami stylistycznymi i gatunkowymi nabożeństwa drogi krzyżowej w XX wieku. Jak wiadomo, klasyczne nabożeństwo tego typu składa się z 14 stacji. Przy każdej z nich na ogół odmawia się krótkie formuły modlitewne mające charakter stały 
oraz wygłasza dłuższe rozważanie o charakterze zmiennym ${ }^{1}$. Osoba odprawiająca nabożeństwo może ułożyć tekst samodzielnie, możliwa jest też niewerbalna kontemplacja męki Chrystusa. Powszechna jest jednak praktyka korzystania z gotowych tekstów publikowanych jako broszurki, a także umieszczanych w modlitewnikach i osobnych zbiorkach. Mogą one służyć jako pomoc dla kapłanów prowadzących nabożeństwo, mogą być także używane przez świeckich do prywatnego odmawiania. Obecnie teksty takie zamieszcza się także w prasie katolickiej oraz w Internecie. Bogaty wybór znajduje się na stronach internetowych zakonów (np. kapucynów, dominikanów), diecezji, sanktuariów i różnych stowarzyszeń religijnych. Niektóre rozważania są anonimowe, wiele jednak ma znanych autorów, nie tylko księży, ale też siostry zakonne i osoby świeckie.

Materiałem badawczym tego artykułu jest 100 tekstów sprzed soboru watykańskiego $\mathrm{II}^{2}$, na ogół z pierwszej połowy XX wieku, oraz dla porównania 100 tekstów współczesnych z końca XX wieku i początku naszego stulecia.

Zaczniemy od kilku wstępnych ustaleń. Odróżniamy wykrzyknienie, czyli eksklamację, od wykrzyknika, czyli interiekcji ${ }^{3}$. Wykrzyknienie funkcjonuje na poziomie składniowym, a wykrzyknik na poziomie leksykalnym, przy czym oczywiście wykrzyknienie może być wyrażone wykrzyknikiem ${ }^{4}$. W niektórych pracach można znaleźć twierdzenie, że wykrzyknienie ma charakter niewerbalny (równoważnika zdania, oznajmienia) (por. Klemensiewicz 1969: 16; Jodłowski 1976: 62), najczęściej jednak uważa się obecnie, że są to również zdania (wypowiedzenia werbalne) (por. Saloni 1993: 127; Grzegorczykowa 1996: 40). $\mathrm{Na}$ potrzeby niniejszego opracowania przyjmiemy, że wykrzyknienia to wypowiedzenia (werbalne i niewerbalne) mające odpowiednią intonację, zwykle w piśmie oddaną znakiem interpunkcyjnym wykrzyknika.

W tym opracowaniu koncentrujemy się na wykrzyknieniach o funkcji emotywnej (najczęściej utożsamianej z ekspresywną) (por. Bühler 1934/2004: 29; Jakobson 1960: 431-473), zatem nie będą nas interesować stanowcze rozkazy czy usilne błagania, mimo zbliżonej intonacji.

Oto kilka przykładów wykrzyknień emotywnych zaczerpniętych z badanego materiału:

O straszne widowisko! Bóg wcielony pod niezbożnymi leży nogami! (Wielicki 1912: 263)

[...] o jakże się dusza moja raduje! (Poznań 1947: 23) (1994).

${ }^{1}$ Na temat drogi krzyżowej z perspektywy teologicznej pisali W. Smereka (1980); J.J. Kopeć

2 Obradował w latach 1962-1965. Należy podkreślić, że sobór stanowi tylko umowną cezurę, na ogół bowiem zmiany w języku nabożeństwa zachodziły stopniowo. Więcej na ten temat: A. Sieradzka-Mruk (2016: 221-225).

${ }^{3}$ Np. Z. Saloni (1993: 127).

${ }^{4}$ Na temat wykrzykników w omawianym nabożeństwie: A. Sieradzka-Mruk (2014b: 37-50). 
Ale co za spotkanie! (Haduch 1921: 16)

Jakież to niesprawiedliwe! (dla młodzieży 2003: 86)

Wystawiono Zbawiciela na pośmiewisko! (dominikanie IV 2013)5

Pewne trudności praktyczne w analizie wiążą się z pracą na materiale pisanym. Przykładowo, niektórzy autorzy mechanicznie opatrują wykrzyknikiem każdą formę wołacza, niezależnie od projektowanej intonacji czy ewentualnych emocji ${ }^{6}$. Wydaje się, że w wielu wypadkach sama forma wołacza nie musi stanowić odrębnego wypowiedzenia pojedynczego, lecz raczej wypowiedzenie składowe będące częścią wypowiedzenia złożonego. Jest tak zwłaszcza wtedy, gdy po wspomnianym znaku wykrzyknika występuje mała litera, a całość może być prozodycznie ujęta jako jedno wypowiedzenie, czyli bez pauzy i intonacji opadającej na formie wołaczowej ${ }^{7}$. Tak jest w następującym fragmencie:

O Jezu! O Maryjo! najsłodsze rozkosze serca mojego, niech cierpię, umieram dla miłości Waszej. (Anioł 1902: 383)

Kolejny problem jest związany $\mathrm{z}$ pojawianiem się $\mathrm{w}$ badanym materiale wypowiedzeń pozbawionych znaku wykrzyknika, zawierających jednak inne wyraziste sygnały ekspresywności, co powoduje, że przy głośnym odczytaniu wymagają one użycia intonacji wykrzyknikowej, jak w poniższych przykładach:

Ach biada mnóstwu grzechów moich, na których zgładzenie potrzeba było, aby Syn Boski na śmierć krzyżową sromotną potępiony został. (Anioł 1902: 348-9)

Już nigdy, Boże mój, nigdy grzeszyć nie będę. (Poznań 1947: 19)

Jakże często poddaję się takim przygnębiającym myślom. (konformistów 2013)

Wypowiedzenia takie interpretuję zatem również jako eksklamacje.

Intonacja i odpowiadający jej znak wykrzyknika mogą być głównymi czy nawet jedynymi wskaźnikami ekspresywności wypowiedzenia na poziomie składniowym, jak w następujących przykładach:

Stoi On tak w cierniowej koronie, ze zbolałym obliczem, ze spuszczonymi oczyma, cały Krwią oblany, cały ranami okryty! (Poznań 1947: 20)

\footnotetext{
${ }^{5}$ W przypisach do tekstów nabożeństw pochodzących z Internetu nie podaję numerów stron.

${ }^{6}$ Analogiczna sytuacja występuje często w nagłówkach współczesnych listów, które bywają opatrywane wykrzyknikiem nawet w korespondencji o bardzo małym stopniu emocjonalności.

7 „Tekst po znaku wykrzyknienia na ogół rozpoczynamy wielką literą, wolno jednak jakkolwiek ten zwyczaj współcześnie jest rzadko stosowany - użyć litery małej, co oznacza na ogół, że następujący po wykrzykniku tekst jest dalszym ciągiem zdania pojedynczego, np. Dzieci! proszę wstać!” (Polański 2006: 143-144). Tu należałoby uściślić, że jeśli uznać wyraz w wołaczu lub wyraz-wykrzyknik za odrębne wypowiedzenie, to następujący fragment tekstu zaczynający się od małej litery jest dalszym ciągiem wypowiedzenia złożonego, nie pojedynczego.
} 
Zabito Boga! (konformistów 2013)

A potem rzucali losy, kto ma wygrać Jego ubranie! (dominikanie V 2013)

Milczę, bo nie chcę się narażać! (o wspótwinie 2013)

Są jednak także konstrukcje składniowe wyspecjalizowane w wyrażaniu emocji. Są to wypowiedzenia z wyrażeniami co za, jak, jaki, ile itp. Nie są to pytania, mimo podobieństwa struktury, ponieważ mają intonację wykrzyknikową, nie pytajną. Oto przykłady:

[...] o co za wyniszczenie! (Haduch 1921: 17)

Co za majestat Boży w tej ciszy u góry [...] (Haduch 1921: 37)

Co za ulga, gdy ktoś przychodzi z pomocą ... (o miłosiernym 2013)

O jakiż miecz bolesci przenika najboleśniejsze Serce Matki [...] (Poznań 1947: 23-24)

Jaka odważna kobieta, przedarła się przez tłum strażników [...] (o miłosiernym 2013)

Jak łatwo jest posegregować ludzi na dobrych i złych (Życiński 2013)

O, jakby obfite trzeba z oczu toczyć krynice! (Anioł 1902: 372)

Ile wydano niesprawiedliwych wyroków! (Trzec. Tys. 2013)

Ile razy rzuciłem się w przepaść! (Poznań 1947: 10)

Tradycyjnie inicjalne wyrazy w cytowanych wypowiedzeniach były określane jako zaimki (pytajno-względne). W ujęciu Romana Laskowskiego należą one do różnych części mowy, ponieważ uwzględnia się tu kryterium fleksyjne (Laskowski 1984: 35). Natomiast Maciej Grochowski zalicza niektóre z tych wyrażeń do klasy modyfikatorów deklaratywności, które nie mogą wystąpić w wypowiedzeniach oznajmujących i mają ustabilizowaną pozycję linearną w wypowiedzeniu, w tym wypadku inicjalną (Grochowski 1997: 26). Jednakże modyfikatory deklaratywności są leksemami nieodmiennymi, a niektóre z wydzielonych przeze mnie wyrazów mają wyraźne cechy fleksyjne i mogą, również w zdaniach wykrzyknikowych, pojawiać się w różnych formach (np. jaki, jaka, jakiej, ile, ilu). Z uwagi na funkcję w wypowiedzeniach emocjonalnych dogodnie będzie posługiwać się tradycyjnym rozumieniem zaimka ${ }^{8}$. Być może dobrym rozwiązaniem byłoby uznanie, że zaimki te w badanych kontekstach sekundarnie wykazują pewne cechy partykuł (modulantów) afektujących.

${ }^{8}$ Klasyfikacja M. Grochowskiego ma jednak zaletę pozwalającą umieścić w tej samej klasie wymienione wyrażenia i wyraz ale, który również rozpoczyna zdania wykrzyknikowe, o czym poniżej. 
Wyrazom tego typu często towarzyszy cząstka $-\dot{z} e,-\dot{z}^{9}$, tradycyjnie uważana za partykułę (modulant), np.:

Jakże często poddaję się takim przygnębiającym myślom. (konformistów 2013)

Cóż za pytanie! (bezrobotnego 2003: 67)

Wypowiedzenia ekspresywne mogą być tworzone także przy pomocy partykuły ${ }^{10}$ ale, chociaż w badanym materiale są to rzadkie przypadki. Przykładem może być zdanie:

Ale im mój Jezus powiedział! (dla młodzieży 2003: 90)

Wydaje się, że cytowane zdanie ma w jakimś stopniu zabarwienie potoczne. W powyższym fragmencie stanowi element stylizacji, o czym obszerniej w końcowej części opracowania.

Wypowiedzenia zaczynające się od co za, jaki/-a/-e oraz ale opisuje Anna Grzesiuk w pracy Skladnia wypowiedzi emocjonalnych (1995: 51). Co ciekawe, autorka omawia je jako równoważniki zdań, podczas gdy w badanym przeze mnie materiale występują dość często także struktury werbalne. W drogach krzyżowych występuje też więcej sposobów tworzenia takich wypowiedzeń niż wymieniła A. Grzesiuk, np. przy pomocy wyrazów ile oraz jak. Wypowiedzenia z tymi ostatnimi operatorami są zresztą w drogach krzyżowych najliczniejsze. Obserwowana różnorodność ma związek ze znaczną emocjonalnością stylu pasyjnego i drogi krzyżowej jako gatunku mowy.

Przejdźmy teraz do porównania dawnych i nowych tekstów nabożeństw.

Najogólniej można powiedzieć, że wypowiedzeń o funkcji emotywnej $\mathrm{w}$ tekstach dawnych jest znacząco więcej. Wiele dróg krzyżowych z początku XX wieku zawiera ich po kilkadziesiąt, skrajny przypadek to 95 eksklamacji ${ }^{11}$. Szczególnie dużo takich konstrukcji występuje w tekstach, których mniej lub bardziej odległym pierwowzorem była droga krzyżowa św. Leonarda da Porto Maurizio $^{12}$ - ponieważ nie są to jednak przekłady, ale bardzo swobodne parafrazy ${ }^{13}$ czy nawet mniej lub bardziej luźne nawiązania, więc w różnych wersjach liczba eksklamacji jest różna - od 41 (Mycielski 1926) do 95. Występują tu dłuższe

${ }^{9}$ M. Grochowski natomiast uważa całe wyrażenia jakże czy cóż za modyfikatory deklaratywności (1997: 26).

${ }^{10} \mathrm{~W}$ tym kontekście ale nie jest oczywiście spójnikiem. W ujęciu M. Grochowskiego byłby to również modyfikator deklaratywności (1997: 26).

11 Bochnia 1900.

12 Autor włoski, żyjący w latach 1676-1751, był jednym z głównych propagatorów nabożeństwa drogi krzyżowej (Fros, Sowa 1998: 599-600). Stad popularność, jakim cieszyły się również o stulecie później napisane przez niego rozważania. Widoczne w nich elementy estetyki barokowej wpływają, jak się wydaje, na częstość występowania eksklamacji.

13 Wiele przedsoborowych dróg krzyżowych można uznać za teksty kliszowane. Więcej na ten temat: A. Sieradzka-Mruk (2015: 339-352). 
fragmenty złożone w całości lub prawie w całości z wypowiedzeń ekspresywnych, jak np. następująca modlitwa przy pierwszej stacji:

O Jezu! mój Jezu! cóż to za niepojęta miłość, ta miłość Twoja ku mnie! Jakto! [sic!] dla tak nędznego stworzenia, jakim ja jestem, nie dość było cierpieć więzienie, skrępowanie, biczowanie, jeszcze potrzeba było, abyś poniósł tak haniebny wyrok! Ach! Na skruszenie serca mojego dosyć już tego; ach! dosyć i zanadto, aby mnie pobudzić do żalu i nienawiści wszelkich złości i brudów języka mojego, które Cię takiej nabawiły hańby. Ach! szczerze ich nienawidzę i żałuję za nie! Ach! gorzko je opłakuję i w tym gorzkim płaczu, idąc Twą bolesna drogą, ustawicznie będę jęczał i wołał: Jezu mój, miłosierdzia! Miłosierdzia, Jezu mój! (paulini 1938: 18)

Istnieją jednak także nieliczne przedsoborowe teksty, w których pojawia się stosunkowo niewiele wykrzyknień np. krótsza odmiana drogi krzyżowej skoncentrowana na aspekcie modlitewnym:

O mój Jezu, którego miłosierdzie podnosi tych, którzy upadają, przebacz tym, którzy Ciebie obrażają przez słabość (Zdrowaś Maria 1949: 150).

Przy każdej stacji pojawia się tu podobna modlitwa zaczynająca się od zwrotu „O mój Jezu" ${ }^{14}$. W cytowanym fragmencie nacechowana emocjonalnie jest tylko ta właśnie początkowa apostrofa, która jednak nie tworzy samodzielnego wypowiedzenia wykrzyknikowego, będąc połączona ze zdaniem względnym. Nawet razem z tym zdaniem nie musi być rozumiana jako eksklamacja ze względów prozodycznych, nie musi być bowiem wymawiana z silną kadencją.

Cytowana droga krzyżowa w badanym materiale występuje również w kilku wariantach jako jeden z kilku tekstów kliszowanych. W modlitewniku Zdrowaś Maria z roku 1949 nie ma ani jednego znaku interpunkcyjnego wykrzyknika, ale w niektórych innych wydaniach tej drogi krzyżowej część zwrotów $O$ mój Jezu, a także inne zdania opatrywane są wykrzyknikiem, np.:

O mój Jezu! użycz mnie [sic!] łaski, żebym nigdy nie odłączał(a) się od Przenajświętszej Matki Twojej (Wianuszek 1928: 212)

O mój Jezu ukrzyżowany, bądź na przyszłość moją jedyną nadzieją i pociechą całego świata! Niech umieram, trzymając krzyż Twój w rękach moich i miłując Cię do końca! (Wianuszek 1928: 216)

Zauważmy, że wykrzykniki pojawiają się tu rzeczywiście w kontekstach budzących silne emocje, gdy mowa o spotkanie Jezusa z Matką oraz o Jego śmierci na krzyżu.

Różna liczba znaków interpunkcyjnych wykrzyknika w różnych wersjach świadczy to o pewnej swobodzie redaktora. Także osoba odprawiająca nabożeństwo w wielu wypadkach zapewne może (ale nie musi) zinterpretować

${ }_{14}$ Jest to przykład środka stylistycznego zwanego anaforą, który tu pełni funkcję delimitacyjną (zob. Okopień-Sławińska 1988: 28). 
głosowo dane wypowiedzenie jako ekspresywne. W omawianej drodze krzyżowej w różnych jej wariantach mamy więc od 0 do 5 znaków wykrzyknienia, co na tle przedsoborowych dróg krzyżowych jest bardzo niewielką liczbą. Jest to związane z krótkością tekstu skoncentrowanego wyłącznie na strukturze modlitewnej. Należy także e zauważyć, że modlitwy te nawiązują wyraźnie do łacińskiego modelu modlitwy liturgicznej (zob. Makuchowska, Przyczyna 2004: 311), w której emocjonalność jest raczej ograniczona. Działa tu więc wpływ stylu liturgicznego.

Innym czynnikiem może być projektowany (wirtualny) odbiorca, np. ks. Henryk Haduch, adresuje swoją wypowiedź do inteligencji i wyraźnie skupia się na bardziej intelektualnych rozważaniach (Haduch 1921: s. 5). W jego tekście, dłuższym niż przeciętna droga krzyżowa, pojawiają się 22 wykrzyknienia, co jest liczbą stosunkowo niewielką na tle innych dawnych tekstów.

Wśród przedsoborowych dróg krzyżowych są to przykłady nietypowe, w najczęstszych przypadkach znajdujemy kilkadziesiąt eksklamacji w jednym tekście.

Natomiast wiele współczesnych tekstów dróg krzyżowych zawiera tylko pojedyncze wypowiedzenia wykrzyknikowe, dotyczy to zwłaszcza znanych autorów współczesnych, jak Karol Wojtyła (1976), Edward Staniek ${ }^{15}$, Adam Boniecki (2013), Józef Życiński (2013), Jacek Stryczek (2011). Zdarzają się także drogi krzyżowe całkowicie takich wypowiedzeń pozbawione ${ }^{16}$.

Dość dużo wykrzyknień natomiast stosuje ks. Tomasz Ważny, co jest najwyraźniej podyktowane stylizacją na język mówiony, a nawet potoczny. Wiąże się to z przemyślaną koncepcją tego autora. Jego rozważania, a także modlitwy są prowadzone $\mathrm{z}$ punktu widzenia osoby, dla której przeznaczono tekst ${ }^{17}$. W tę koncepcję dobrze wpisują się też tytuły: Droga krzyżowa męża i ojca, Droga krzyżowa żony i matki, Droga krzyżowa bezrobotnego, Droga krzyżowa człowieka, który ma władzę (Ważny 2003). Ta konstrukcja z dopełniaczem ma zapewne podkreślić aktywność duchową uczestnika nabożeństwa.

Oto kilka przykładów wypowiedzeń wykrzyknikowych w tekstach ks. T. Ważnego stylizowanych na język mówiony:

A tu taki pech! (bezrobotnego 2003: 61)

Ale warto! [...] Ależ nie! (człowieka 2003: 14 )

Jak ja ich nie lubię ! Tego tępego, żądnego sensacji i rozrywki jerozolimskiego thumu! [...] Ale im mój Jezus powiedział! [...] Pokazać trzeba, że śmierć Jezusa jest czymś najważniejszym! Jedynym! Największym! (dla mtodzieży 2003: 89-93)

${ }^{15}$ Np. wiara 2013.

16 Np. mądrość 2013; Śr.Popiel. 2013.

17 Problem nadawcy i odbiorcy drogi krzyżowej, zarówno realnego jak i wirtualnego, należy rozważać w kategoriach opisywanego w tekstach religijnych tzw. rozszczepienia komunikacyjnego (M. Wojtak 2011: 35-38). 
Wśród różnych zjawisk można tu zauważyć powszechne dla składni mówionej, zwłaszcza w wypowiedziach emocjonalnych, usamodzielnienie intonacyjne członów zdaniowych (Grzesiuk 1995: 127).

Eksklamacje w wypowiedziach stylizowanych na język mówiony (potoczny) stosują także niekiedy inni autorzy, np.

Jak też niektórzy muszą się stale pakować w kłopoty i jeszcze trzeba im ustawicznie pomagać [...] (dk.homilie V 2013)

A cóż to jest prawda? Toż to tylko ułuda i utopia! (prawdy 2013)

Stylizacją na język potoczny wyróżnia się też droga krzyżowa ks. A. Katoli. Por. przykłady:

Och nie, tylko nie to! [...] Widzicie Go! [...] Ty, nie wygłupiaj się!!! (Katolo 2013).

Występują tu kolokacje typowe dla mowy potocznej, które w cytowanym tekście mają wydźwięk ironiczny. Należy zauważyć, że ironia była zjawiskiem zupełnie obcym przedsoborowej drodze krzyżowej.

W ostatnim cytowanym przykładzie, a także w niektórych innych współczesnych tekstach, szczególnie zamieszczonych w Internecie, ale nie tylko ${ }^{18}$, nowym interesującym zjawiskiem jest mnożenie znaków wykrzyknika, a także używanie innych graficznych wyróżników (np. dużych liter), które przy głośnym odczytaniu mają zapewne również oznaczać szczególnie wyraźną intonację wykrzyknikową, a także akcent zdaniowy na wyróżnionym wyrazie:

Oni wszyscy razem z Tobą krzyczą: „Śmierć jest absurdem!!” (dk.homilie V 2013)

Nie cierpiałabyś tyle !!! ([Katolo 2013)

[...] a ja nie mam czasu, a ja chcę żyć spokojnie !!! (dk.homilie V 2013)

Drugi upadek Chrystusa to dla Ciebie przypomnienie, ostrzeżenie, ALARM!!! [sic!] (konformistów 2013)

...Pan zwalił na Niego winy nas wszystkich ... i moje także!!! moje także!! (dk.homilie IV)

W tych wypadkach duży wpływ mają cechy zarówno rzeczywistych, jak i wirtualnych nadawców i odbiorców (np. młody wiek, określone środowisko), co można byłoby poddać dalszym badaniom, m.in. socjolingwistycznym.

Jak wskazuje analiza, frekwencja wykrzyknień emotywnych we współczesnych drogach krzyżowych uległa wyraźnemu zmniejszeniu w porównaniu do tekstów z początku XX wieku. Jest to jeden z elementów pozwalających postawić tezę $\mathrm{o}$ zmianach $\mathrm{w}$ hierarchii funkcji wypowiedzi $\mathrm{w}$ omawianym nabożeństwie

${ }^{18}$ Zob. także np. dla kobiet (2012: 189). 
zachodzących w XX wieku ${ }^{19}$. Widoczna jest jednak zależność od indywidualnego stylu autora, wpływu innych stylów funkcjonalnych oraz wielu innych czynników związanych z sytuacją komunikacyjną.

\section{Skróty cytowanych źródeł 20}

Aniol 1902: Droga Krzyża Jezusowego to jest nabożeństwo, które, kiedy kto nabożnie odprawi, otrzyma te odpusty, które otrzymuja nawiedzajacy miejsca św. w Jeruzalem, w: Aniot Stróż chrześcijanina katolika. Zbiór modtów i pieśni stużacy dla dusz pobożnych. Z dodatkiem nieszporów i pieśni łacińskich, Grudziądz 1902? [b.r.w.] ${ }^{21}$, s. 345-388. bezrobotnego 2003: Ważny T., Droga krzyżowa bezrobotnego, w: tegoż, 2003, Pójde z Toba droga krzyża, Kraków, s. 58-69.

Bochnia 1900: Droga Krzyżowa ułożona przez św. Leonarda de Porto Mauricio, które to nabożeństwo corocznie w kolizeum [sic!] w Rzymie uroczyście się obchodzi, 1900, Bochnia.

Boniecki A., 2013, Rozważania drogi krzyżowej, http:// ww.drogakrzyzowa.kapucyni.pl [dostęp: 15.03.2013].

człowieka 2003: Ważny T., 2003, Droga krzyżowa człowieka, który uczy się kochać, w: idem, Pójdę z Toba droga krzyża, Kraków, s. 7-17.

dk.homilie IV 2013: Droga Krzyżowa IV http://www.dk.homilie.org [dostęp: 15.03.2013]. dk.homilie V 2013: Droga Krzyżowa V http://www.dk.homilie.org [dostęp: 15.03.2013]. dla kobiet 2012: Droga krzyżowa z rachunkiem sumienia, w: Rogalska M. (oprac.), 2012, Modlitewnik dla kobiet, Kraków, s. 187-191.

dla młodzieży 2003: Ważny T., Droga krzyżowa dla młodzieży, w: tegoż, 2003, Pójde z Toba droga krzyża, Kraków, s. 86-95.

dominikanie V 2013: Droga Krzyżowa $V$ http://www.dominikanie.com [dostęp: 15.03.2013].

Haduch H., 1921, Śladami Chrystusa. Krótkie rozmyślania na temat drogi krzyżowej, Kraków.

Katolo A., 2013, Droga krzyżowa naszych czasów http://th-www.if.uj.edu.

pl/ gierula/Parafia/Rekolekcje/wpost99/viaxy.htm [dostęp: 15.03.2013].

konformistów 2013: Droga krzyżowa I (konformistów...), http://www.wielkipost.awardspace.com [dostęp: 15.03.2013].

madrość 2013: Staniek E., Modlitwa o madrość. Droga Krzyżowa XIII, http://www.drogakrzyzowa.kapucyni.pl [dostęp: 15.03.2013].

Mycielski M., 1926: Droga Krzyżowa wedtug św. Leonarda ułożona przez ks. M. Mycielskiego T.J. i Gorzkie żale, Kraków.

${ }_{19}$ Więcej na ten temat: A. Sieradzka-Mruk, Przemiany nabożeństwa drogi krzyżowej w XX wieku w świetle teorii aktów mowy [w druku], w tomie materiałów z konferencji Polska kultura religijna, zorganizowanej w 2015 r. w Krakowie przez Akademię Ignatianum.

${ }^{20} \mathrm{~W}$ tytułach źródeł stosujemy zapis oryginalny, nie zawsze zgodny z normą ortograficzną i interpunkcyjną.

${ }^{21}$ Bardzo często, zwłaszcza w starszych modlitewnikach, pomijano datę wydania (także inne dane). Przybliżoną datę ustalamy wówczas na podstawie zamieszczonej w modlitewniku tablicy świąt ruchomych lub daty imprimatur. 
o miłosiernym 2013: Droga Krzyżowa o miłosiernym Zbawicielu, http://www.milosierdzieboze.pl [dostęp: 15.03.2013].

o współwinie 2013: Droga Krzyżowa o współwinie, strachu i obojętności, http://www. dominikanie.com [dostęp: 15.03.2013].

paulini 1938: Droga krzyżowa. Gorzkie żale i kilka pieśni wielkopostnych, Częstochowa 1938.

Poznań 1947: Droga Krzyżowa, 1947, Poznań.

Prawdy 2013: Droga Krzyżowa III (Prawdy), http://www.dk.homilie.org [dostęp: 15.03.2013].

Stryczek J., 2011, Korporacyjna droga krzyżowa, http://www.rp.pl/artykul/646730.html [dostęp: 15.03.2013].

Śr. Popiel. 2013: Karuk E., Środa Popielcowa, w: tegoż, Droga krzyżowa na wszystkie dni Wielkiego Postu, http://www.opoka.org.pl [dostęp: 15.03.2013].

Trzec. Tys. 2013: Droga Krzyżowa Trzeciego Tysiaclecia, http://www.dominikanie.com [dostęp: 15.03.2013].

Ważny T., 2003, Pójdę z Tobą droga krzyża, Kraków.

Wianuszek 1928: Stacje drogi krzyżowej, w: Wianuszek Marji! Ksiązeczka do nabożeństwa dla wszystkich wiernych katolików, 1928, Kraków, s. 211-217.

wiara 2013: Staniek E., Panie, przymnóż nam wiary. Droga krzyżowa XVII, http://www. drogakrzyzowa.kapucyni.pl [dostęp: 15.03.2013].

Wielicki J. 1912: Droga Krzyżowa, w: Zdrowaś Marja. Zbiór modlitw, zebrat i ułożył..., Warszawa 1912, s. 256-287.

Wojtyła K. (Jan Paweł II) 1976: Droga krzyżowa, w: Wojdecki W., 1985, Wierzę w Ciebie, Boże żywy, Warszawa, s. 371-383.

Zdrowaś 1949: Droga Krzyżowa czyli Stacje Męki Pańskiej, w: Zdrowaś Maria. Zbiór modlitw i pieśni na wszystkie uroczystości kościelne w roku dla ptci obojga, Warszawa 1949, s. 149-154.

Życiński J. 2013: Droga krzyżowa, http://www.tygodnik.onet.pl [dostęp: 15.03.2013].

\section{Bibliografia}

Bühler K., 1934/2004, Teoria języka. O językowej funkcji przedstawiania, Kraków.

Fros H., Sowa F., 1998, Księga imion i świętych, t. 3, Kraków.

Grochowski M., 1986, Polskie partykuły. Składnia, semantyka, leksykografia, Wrocław.

Grochowski M., 1997, Wyrażenia funkcyjne. Studium leksykograficzne, Kraków.

Grzegorczykowa R., 1996, Wykłady z polskiej składni, Warszawa.

Grzesiuk A., 1995, Składnia wypowiedzi emocjonalnych, Lublin.

Jakobson R., 1960, Poetyka w świetle językoznawstwa, „Pamiętnik Literacki”, z. 51, s. 431-473.

Jodłowski S., 1976, Podstawy polskiej składni, Warszawa.

Klemensiewicz Z., 1969, Zarys sktadni polskiej, Warszawa.

Kopeć J.J., 1994, Droga krzyżowa. Duchowość nabożeństwa i antologia współczesnych tekstów polskich, Niepokalanów.

Laskowski R., 1984, Podstawowe pojęcia morfologii, w: Gramatyka współczesnego języka polskiego, red. R. Grzegorczykowa i in., Warszawa, s. 9-57.

Makuchowska M., Przyczyna W., 2004, Przed nowa edycja ,, Mszału Rzymskiego” w Polsce. O języku przekładu tekstów liturgicznych, w: Kościół w życiu publicznym. Teolo- 
gia polska i europejska wobec nowych wyzwań, t. 2: Materiały spotkań sekcyjnych, Lublin, s. 309-322.

Okopień-Sławińska A., 1988, Anafora [hasło], w: Słownik terminów literackich, red. J. Sławiński, Wrocław, s. 28.

Polański E., 2006, Zasady pisowni i interpunkcji, w: Wielki stownik ortograficzny PWN, red. E. Polański, Warszawa, s. 9-151.

Saloni Z., 1993, Eksklamacja (wykrzyknienie) [hasło], w: Encyklopedia językoznawstwa ogólnego, red. K. Polański, Wrocław, s. 127.

Sieradzka-Mruk A., 2014a, Innowacje gatunkowe współczesnej drogi krzyżowej, w: Bogactwo współczesnej polszczyzny, red. P. Żmigrodzki, S. Przęczek-Kisielak, Kraków, s. 309-316.

Sieradzka-Mruk A., 2014b, Zmiany w funkcjonowaniu i częstości występowania wykrzykników (interiekcji) w rozważaniach drogi krzyżowej w ciagu ostatniego stulecia, „Język Polski”, z. 1, s. 37-50.

Sieradzka-Mruk A., 2015, Przemiany schematu kompozycyjnego drogi krzyżowej w XX wieku, w: Dialog z tradycją. Język, komunikacja, kultura, t. IV, red. R. Dźwigoł, I. Steczko, Kraków, s. 339-352.

Sieradzka-Mruk A., 2016, „Radość i nadzieja, smutek $i$ trwoga” w nabożeństwie drogi krzyżowej. Wybrane aspekty ewolucji dyskursu religijnego $w$ XX wieku na przykładzie leksyki dotyczacej uczuć, Kraków.

Smereka W., 1980, Drogi krzyżowe. Rys historyczny i teksty (studium pasyjne), Kraków.

Wojtak M., 2011, Współczesne modlitewniki w oczach językoznawcy. Studium genologiczne, Tarnów. 
